\title{
Cloverleaf skull-asphyxiating thoracic dysplasia syndrome
}

INSERM

\section{Source}

INSERM. (1999). Orphanet: an online rare disease and orphan drug data base. Cloverleaf skull-asphyxiating thoracic dysplasia syndrome. ORPHA:100978

Cloverleaf skull-asphyxiating thoracic dysplasia is a rare syndromic craniosynostosis characterized by prenatal presentation with cloverleaf skull, micromelia and asphyxiating thoracic dysplasia. Radiologic features include short ribs, horizontal roof of the acetabulum with a rounded median prominence and lateral spurs, deformed long bones with broad metaphyses, and absent ossification of the terminal phalanges. There have been no further descriptions in the literature since 1987. 